\title{
Iconic Power, Dark Tourism and the Spectacle of Suffering
}

Eamonn Carrabine

In Hodgkinson, Sarah, Piché, Justin, Walby, Kevin and Jacqueline Z Wilson (eds) The Palgrave Handbook of Prison Tourism, London: Palgrave.

In this chapter I explore some of the ethical questions posed by dark tourism and the spectacle of suffering through two examples ${ }^{1}$. One is of Ai Weiwei's temporary exhibition on Alcatraz, which juxtaposes extraordinary conceptual art installations in one of the major sites of prison tourism, to explore the relationships between art and activism in carceral space. The second is the display of genocidal evidence at both the Khmer Rouge 'security centre' codenamed S-21, which was a former high-school in Phnom Penh, the capital of Cambodia, and the 'Killing Fields' of Choeung Ek, ten miles east of the capital, where prisoners were taken to be executed. Recognising that dark tourism involves a 'fluid spectrum of intensity' (Stone, 2006:146) the museum experience is nevertheless central to it where representations of death, disaster or atrocity are displayed for an uneasy mix of education, commerce and memorialisation purposes. At the lighter end of the scale are those sites loosely associated with violence and trauma, examples of which would include the London Dungeon or the proposed Dracula theme park in Romania, these are 'firmly entertainment focussed and commercialised' while toward the middle and combining 'education and entertainment' are prison tourist sites, whereas the 'darkest' places (such as holocaust museums) are locations that 'can invoke sombre reflection, grief, sorrow, shock and horror' (Barton and Brown, 2015:238). As such the latter belongs to a broader 'thanatoptic' tradition of visiting sites of death, disaster and the macabre, which have been an integral feature of tourism long before the twentieth century (Seaton, 1996, 2009), but the scholarship in this area is said to lack 'a theoretical relationship to wider studies of violence and by-standing' (Keil, 2005:481). There is evidence to suggest that this is changing, not least as dark tourism becomes an object of criminological attention (as this edited collection attests), but geographers have also begun to examine the logics of administrative violence in 'atrocity photography' (Tyner and Devadoss, 2014) in ways that have much to offer our understanding of spectacles of suffering and the politics of remembrance at these disturbing sites, attractions and exhibitions.

The chapter takes a cue from Andreas Huyssen's (1995:255) argument that one of the reasons 'for the newfound strength of the museum and the monument in the public sphere may have something to do with the fact that both offer something that television denies: the material quality of the object'. Here the focus on extreme histories is bound up with a contemporary culture fascinated with memory and gripped by a fear of forgetting in the face of so many fleeting images encountered on screen and the very 'immateriality of communications' (Huyssen, 1994:12). The concept of iconic power is used to examine the boundaries of representation, and the different ways visual memories and historical testimony are mobilised. Critics have raised concerns over the ways in which leisure and pleasure are mixed with tragedy at the sites of dark tourism, and the chapter will discuss why the practice has been condemned as an inappropriate and immoral way to publicly commemorate human suffering and distressing events. The chapter begins by situating the concept of iconic power in cultural sociology, as it has some significance for understanding how rituals of remembering might access the pass. Not least since the recent resurgence of interest in 'collective memory' across a range of different disciplines, which include cultural studies, history, literature, social psychology and sociology, can be traced back to Maurice Halbwachs (1925/1992) conceptualisation of it. 
Halbwachs drew on Durkheim (1912), especially with regard to the 'collective consciousness', which provides members of a society a shared identity and group allegiance. He argued that, 'Memory needs continuous feeding from collective sources and is sustained by social and moral props. Just like God needs us, so memory needs others'

(Halbwachs,1925/1992: 34). Today, of course, the 'continuous feeding' of collective memory has much more to do 'with the connectivity of the electronic media than with any sustained social consensus about the past' (Hoskins, 2003:7). The rise of the mass media has been accompanied by the democratisation of travel and visits to notorious places of violent death have become a feature of the recreational landscape promoted by the heritage/tourist industry. At these sites items, objects and the location itself become collectively significant through a process of 'sacralisation' (Urry, 1990:9-10) and frequently invite comparison with pilgrimage (Keil, 2005:480). Indeed, Rainer Schulze (2014:124) distinguishes between 'pilgrims' and 'tourists' in his discussion of those who visit Holocaust memorial sites, where the former "come to mourn the people who died and suffered at the camps, honour their memory and learn more about the context and practice of their incarceration', while the latter are those who visit 'because the site exists and often is on a tourist trail or who are fascinated by the deaths that occurred there'. In either case the places and the objects associated with them have become steeped in iconic power and it is the tensions exposed by this 'iconicity' that lie at the heart of this chapter.

The chapter begins by discussing the concept of 'iconic power' in relation to recent developments in cultural sociology, where a strong Durkheimian presence is now registering, and how this work dismisses some crucial insights from other social theorists that can help shed light on aesthetic questions and the consumption of trauma at the sites of dark tourism. There then follows a closer look at the 'museum effect', which is produced through the interplay of objects, images and space, and is integral to how tourists encounter dark heritage. These issues are explored in two examples. The first is a temporary conceptual art installation at Alcatraz, which was an ambitious attempt to radically shift the meanings of incarceration at the notorious site and the pieces themselves - ranging from the monumental to the intricate - certainly interrogated the question of place in quite challenging ways. The second example focuses on Cambodia's 'Killing Fields' and S-21 secret prison in an effort to analyse iconic power and the spectacle of suffering in a non-Western setting. It is because of the scale of the atrocities committed by the Khmer Rouge in the 1970s that a complex politics of memory has arisen in the country since the genocide and these sites are often experienced as theatres of macabre spectacle prompts important ethical questions on the display of crime at them and in the global circulation of a horrific past.

\section{Iconic Power and Cultural Sociology}

It is important to situate the work on iconic power in the context of the 'strong program' in cultural sociology, which has emerged as a 'significant and confident intervention, designed to re-orientate sociology and cultural studies alike in quite fundamental ways' (McLennan, 2005:1). Since the 1990s it has established an academic base (Yale Center for Cultural Sociology), book series (Palgrave), handbook (Oxford Handbook of Cultural Sociology), and since 2013 also a journal (American Journal of Cultural Sociology). Alexander is the leading light in this new American cultural sociology, which he and his students sharply differentiate from other competing approaches like Bourdieu's sociological analysis, Birmingham cultural studies and Foucauldian governmentality perspectives - all examples of which are 
condemned for treating culture as a 'feeble and ambivalent variable' (Alexander, 2003:6-7). These are formidable targets and the clear implication is they are 'weak' approaches that reduce culture to a product of social structure or materialist elements like class, interests or power. In contrast, the 'strong program' is committed to an autonomous conception of culture and is dedicated to revealing the pivotal role culture plays in shaping social life. The approach was spelled out in 1988 in his introduction to the edited collection Durkheimian Sociology: Cultural Studies, which is premised on an argument that the later writings of Durkheim provides a vital resource for contemporary sociology and its focus on symbolic process. This later scholarship culminated in The Elementary Forms of Religious Life (1912) and the move to the study of religion in Durkheim was 'because he wanted to give cultural processes more theoretical autonomy' (Alexander, 1988:2). In this account Durkheim is seen as providing an important, if largely unacknowledged, legacy for the development of semiotic and ritual analysis.

Over the years, this neo-Durkheimian framework has been deployed in a variety of empirical contexts, including race (Jacobs, 2000), punishment (Smith, 2008) and politics (Ku, 1999), where the theoretical drive emphasizes the collective conscience at work in civil society. One strand has been to focus on 'cultural trauma' in Alexander's (2002:5) own study of the Holocaust to demonstrate 'that even the most calamitous and biological of social facts - the prototypical evil of genocidal mass murder - can be understood only inside of symbolic codes and narratives'. There is, of course, an extensive literature on Holocaust memorialisation and it has set much of the terms of debate over which, if any, strategies are the most ethically appropriate to collectively remember the traumatic past. These disputes will be examined in more detail in what follows, but it is also important to note that Philip Smith's (2008) attempt to reinterpret every significant penal institution - from public executions, through the panopticon and guillotine up to the electric chair and supermax prisons - has also been influential in studies of penal tourism (Welch, 2012, 2013, 2015, Welch and Macuare, 2011).

Smith's (2008) Punishment and Culture, is a book that self-consciously sets out to demolish what it sees as the dominant theoretical approach in the field. This is taken to be what he condemns as 'hermeneutically thin' power-and-control perspective derived from Foucault, which he seeks to replace with a 'radically anti-Foucauldian position'. The alternative perspective is a neo-Durkheimian one that is a product of the "strong program in cultural sociology' and the work can be understood as a 'contribution to that project' and 'an extended demonstration of what a muscular cultural sociology can make to a specific field - a field which in this case is punishment and penal institutions' (Garland, 2009:260). And in doing so the book carries a 'polemical force that dramatizes Smith's claims' but in a way that overstates them to such an extent that it has 'the paradoxical effect of undermining them (ibid:265). In the drive to push his Durkheimian themes to the centre of analysis the originality of his insights are somewhat marginalized by the excessive need to prioritize this form of sociological explanation over other approaches. Ultimately this is a project 'persistently dogged by an ultimately one-sided preference for idealist formulations and valuations' and reveals the limits of the critical purchase of this specific brand of cultural theory (McLennan, 2005:1-2). Others have sought to defend neo-Marxist and materialist perspectives against this brand of cultural sociology, but I have no wish to replace a onesided idealist argument, with another equally one-sided materialist position. As Vic Gatrell (1994:25) put it, only 'rash historians would privilege material or political or cultural causes 
without interrelating all three' and this injunction is one that needs to be kept firmly in sight as the field is theoretically reconfigured.

More recently an 'iconic turn' has been announced by proponents of the 'strong program' in cultural sociology (Bartmański and Alexander, 2012). Building on Durkheim's classic analysis of totemism, where he explained how the power of sacred symbols derived from their ability to represent collective identity, the iconic turn is geared toward grasping the very materiality of an image. In this understanding an image is more than simply a 'projection of social meanings: it is a complex sensory experience' (Sonnevend, 2012:219). Iconicity is concerned with 'experiencing material objects, not only understanding them cognitively or evaluating them morally but also feeling their sensual, aesthetic force' (Bartmański and Alexander, 2012:1). The cultural sociology of iconic power highlights the interactions between aesthetic surface and discursive depth. In doing so, this work can be read as an attempt to take a position in the rapidly expanding field of interest in visual culture across the humanities and social sciences, and will be explored in more detail in the chapter. They note, for example, how:

The logencentrism of modern Western culture (Jay 1994) has downplayed the visual surface, maintaining that it is preceded by depth and, therefore, merely reflects it. Postmodern theory inverts this thesis, downplaying discursive meaning and giving priority to the physicality of surface...If logocentrism unduly represses the surface, postmodern thinkers go too far the other way. Their stance runs the risk of being iconoclastic á rebours. Identifying meaning with discourse and reason, and presence with image and emotion, postmodern theory reproduces the old dualisms instead of reconfiguring them.

(Bartmański and Alexander, 2012:4)

Critics have pointed out how this 'iconic turn' has largely ignored already existing work in the social sciences, which has not only addressed the social production and consumption of culture, but has also analyzed the objectifying power of material objects (Santoro and Solaroli, 2016). A major absence is the sociology of Bourdieu, who from his early work on photography through to his later writing on art and culture, offers rich interpretive insights that are neglected in this reframing of iconic power.

One significant omission is Bourdieu's relationship to the art historian Erwin Panofsky, who is widely regarded as founding the modern study of iconology in the 1920s and 1930s (and thus anticipating the iconic turn by several decades, which I discuss in more detail in Carrabine, 2016). Panofsky further refined the method in his Gothic Architecture and Scholasticism (1951). The book was later translated by Bourdieu (1967) and published with a postface where he discusses the sociological significance of Panofsky's study, especially in the concept of 'habitus' for describing the relationship between predispositions acquired through educational institutions and the aesthetic rules of composition deployed in medieval architecture. In a subsequent essay Bourdieu (1968/2003) draws on Panofsky's layered levels of signification to demonstrate how art connoisseurship marks out status distinctions and lends itself to a charismatic ideology of taste, which functions as an important form of cultural capital. Although the 'strong program' has largely ignored Bourdieu's work, for the reasons outlined above (and which I do not share), their ambition to broaden 'sociological epistemology in an aesthetic way' (Bartmański and Alexander, 2012:5) is important and one I 
develop in what follows. Not least since there remains hardly any consensus over how 'the visual' should be analyzed or explained (Wilkinson, 2013:262).

These tensions are very much to the fore in Bourdieu's own work. During his extensive fieldwork in Algeria in the late 1950s and early 1960s he took thousands of photographs documenting the suffering experienced in a colonial war, yet only a few were ever published in his writing about the period. Most would remain unknown until 2000 when they were exhibited and subsequently published in his Picturing Algeria (2012). The relationship between his photographic record and issues of politics, ethics and aesthetics have been discussed by Les Back (2009:473), where he makes the telling remark that 'as a profession we are just not very good at looking at photographs for their sociological value'. In order to do so we can draw on two fundamental points. These can be summarised as follows:

The first is that images do not simply have a representational power in depicting an external reality but that they possess a performative power upon this reality, simultaneously constituting it in meaning...The second...is that our moral and political response to images of vulnerability and violence is not only a question of personal convictions or intimate emotions, but primarily a product of the collective imaginations of the world, of self and other, that such imagery disseminates and legitimises in our (Western) societies.

(Chouliaraki and Blaagard, 2013:254, emphasis in original)

As these authors go on to argue images of other people's suffering not only depict the world as it is, but also prompt emotions and ideas about how the world might be.

\section{The Museum Effect and the Exhibitionary Complex}

These are important arguments, and they remind us that sociology continues to have some fraught encounters with the aesthetic (Olcese and Savage, 2015). Just under two decades ago it could be claimed that 'visual representations. . have been largely ignored in the social sciences', which is indicative of a 'deep mistrust' of images (Holliday, 2000:503-4) in disciplines like anthropology, economics, geography and sociology, where the uses of visual material in social research has long been marginalised. Yet since then there has been a striking proliferation of diverse research methods across the social sciences, and while it is often argued that this growth is due to the increasing prominence of visual images in social life and cultural practice, it is a relationship that has yet to be fully interrogated (Rose, 2014). Although images are often integral to the prison tourist experience they need to be situated in an understanding of what has been called the 'museum effect' (Casey, 2003, Williams, 2007). As Michael Welch $(2013,2015)$ notes in his account of penal tourism, this effect is produced by the complex interplay of objects, images and space. Crucially, it is achieved through a form of "organized walking" in which an intended message is communicated in the form of a (more or less) directed itinerary' (Bennett, 1995: 6). It is this choreographed movement through institutional space, combined with the allure of artefacts and practices that allow visitors to connect with a particular visualisation of the past. The museum offers a distinct 'way of seeing' where the tendency is to 'isolate something from its world, to offer it up for attentive looking and thus to transform it into art' (Alpers, 1991:27). Museums are not just repositories of valuable objects deemed worthy of being preserved, but rather they 'make objects valuable by gathering them' (Casey, 2003:2) and are premised on the 'aura of the authentic historical artefact' (Urry, 1990:129). The museum effect works by forging 
connections between past and present, where the sightseeing is intimately tied to place. In the context of atrocity tourism it is ultimately place, rather than objects or images, that 'gives form to our memories' and 'provides the coordinates for the imaginative reconstruction of the "memories" of those who visit memorial sites but never knew the event first hand' (Williams, 2007:102).

There has been an extraordinary growth in the number of museums around the world, to the extent that a museum on almost any subject can be created somewhere. In his discussion of the 'postmodern museum' John Urry notes how there are some seemingly:

unlikely museums which nevertheless succeed are a pencil museum in Keswick, a museum of the chemical industry in Widnes, a former Gestapo prison cells museum in Berlin, a Japanese prisoner-of-war museum in Singapore, a dental museum in London, and a shoe museum in Street.

(Urry, 1990:134)

Each of these remain committed to the principles of 'show and tell' that is a defining feature of what Tony Bennett (1995:6) terms the 'exhibitionary complex'. And place is the key dynamic here - whether it be associated with an industry, occupation, celebrity figure or traumatic event - and they each have to compete with heritage centres, theme parks and popular festivals that further make up the recreational landscape and vie for tourist visitors. It was in the early nineteenth century that the museum and the fair emerge as distinct sites, involving quite opposing 'orderings of time and space' (Bennett, 1995:5). Bennett build his argument from Foucault's (1967/1986) essay 'Of other spaces' which draws a vivid contrast between the modern idea of the museum and library, with the carnival wonders of the fairground.

Both the museum and the library are a defining characteristic of nineteenth-century Western culture, where:

the idea of accumulating everything, of establishing a sort of general archive, the will to enclose in one place all times, all epochs, all forms, all tastes, the idea of constituting a place of all times that is itself outside of time and inaccessible to its ravages, the project of organizing in this a sort of perpetual and indefinite accumulation of time in an immobile place, this whole idea belongs to our modernity.

(Foucault, 1967/1986:26)

Running contrary to these new institutions are those other spaces linked to time in the most fleeting of ways. The example he gives of such heterotopia are 'the fairgrounds, these marvelous empty sites on the outskirts of cities that teem once or twice a year with stands, displays, heteroclite objects, wrestlers, snake-women, fortune-tellers, and so forth (ibid:26). The terms of the opposition between museum and fair, which revolved around order and disorder, education and entertainment, high and low culture were important in establishing the legitimate social authority of the museum over the unruly fair. However, there are, as Bennett (1995:4) argues, significant processes that have eroded the distinctions between the two, not least the emergence later in the nineteenth century of the fixed-site amusement park that occupied a space between the contrasting values embodied in the scientific museum and travelling fair. In his discussion of the 'birth of the museum', situated historically alongside 
that of the fair and the international exhibition, which like libraries and public parks also had an improving and rational orientation, so that the inferior classes might learn from these places of popular assembly. Public parks, for example, were developed by Victorian social reformers as a reaction against the urban squalor of street culture and aimed to improve citizens through an idyllic, bucolic vision of nature as a form of pastoral recreation.

It has been noted how the importance of place and institutional space in the museum experience are topics frequently overlooked in the field (Williams, 2007, Welch 2015). This absence is partially explained by the influence of art history on the academic study of museums, where the attention is focused on the meaning of artifacts and how they encourage distinctive ways of seeing art. In his influential account of Museums Without Walls, Malraux (1967) describes how the museum effect is produced by the very placing of an object, separating it from its world, but offered up for close viewing in a museum setting actively 'creates its importance and validity' (Casey, 2003:2). He posed the question of whether crafted objects like Romanesque capitals or Renaissance altarpieces are appropriately looked at in museums, when they were not made to be displayed in this way and are severed from their ritual sites. For some art historians and some historical artifacts the 'museum effect' is a positive force, where 'the invitation to look attentively remains and in certain respects may even be enhanced' (Alpers, 1991:27). Yet museums can also make it hard to see, as Alpers (1991) readily acknowledges in her discussion of the difficulties involved in exhibiting seventeenth century Dutch art and culture.

The academic neglect of spatiality is all the more surprising since museums are "partly distinguished from other forms of historical representation by their "sited-ness"" (Williams, 2007:77). However, the significance of space and local embeddedness has been recognised in studies of prison museums - not least since they succeed in achieving their effects through spatial registers that produce striking, if somewhat contrived experiences. The distinctions drawn between 'bogus' and 'authentic' history have been called into question by those who push for 'more attention to the authorial intentions and authenticating devices at work in heritage sites' (Strange and Kempa, 2003:387). In doing so, those who design them are aware that prison museums operate through at least two forms of spatial orchestration:

First, those sites serve as concrete objects in space intended to serve practical purposes (e.g., a building inside where artifacts are displayed). Second, the physical layout contributes to the mental images that visitors create, especially with respect to the topic at hand (e.g. a history of incarceration).

(Welch, 2015:45)

Once a carceral space is transformed into a tourist attraction various items of penal identification, which would include the display of personal objects, torture devices, documentary photography and recorded testimony, are all added to highlight the suffering of prisoners. The curatorial intention is to furnish greater historical understanding and emotional connection with the experience of imprisonment. As Williams (2007:103-4) argues, the topographies of memorial museums are such that 'they seek to support a wide, open-ended variety of practices in visitors, yet also aim to make some authortitative statement about where and how to remember the past'. These arguments will now be discussed through two contrasting case studies of dark tourism, which shed light on the meanings generated by place and memory. 


\section{Traces of Alacatraz}

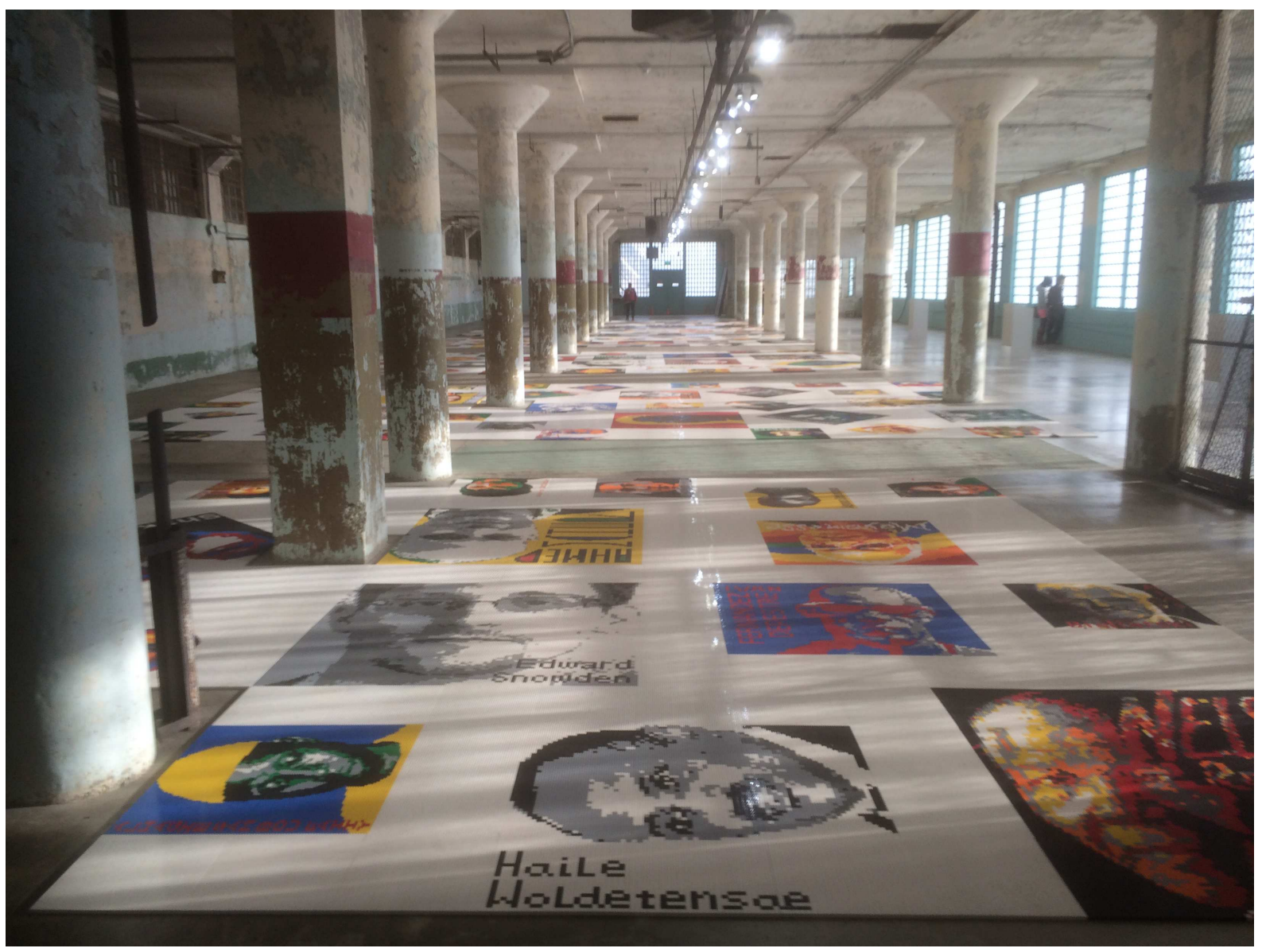

Figure 1: 'Trace' from @Large: Ai Weiwei on Alcatraz.

Photograph: Eamonn Carrabine, November 2014.

Figure 1 is my attempt to capture something of the scale of Ai Weiwei's ambitious art installation at Alcatraz, the infamous island penitentiary in San Francisco bay. 'Trace' is one of seven major artworks he exhibited at the former penal complex from September 2014 through to April 2015 and this one consists of carpets of 1.2 million Lego blocks depicting, in pixelated but legible portraits, more than 175 prisoners of conscience (further details can be found at http://www.for-site.org/wp-content/uploads/2014/12/Trace-Reference-Guide1.pdf). The first panel includes Edward Snowden, Nelson Mandela and Chelsea Manning, but also many lesser known figures who have been imprisoned or exiled because of their beliefs or affiliations. Weiwei is one of China's leading dissident artists, imprisoned in 2011 for 81 days and prohibited from travelling abroad, his work explores themes of freedom, confinement and suppression in politically charged ways. Pieces of the installation were created in the artist's studio in Beijing, while others were entrusted to his assistants and volunteers in San Francisco assembling a multitude of parts under his distant direction.

It is highly significant that the island itself has a multi-layered history, ranging from a 19thcentury military fortress, a notorious federal penitentiary, a site of Native American heritage and protest, and now one of America's most visited national parks and popular tourist 
destinations. Around 5,000 people per day, arriving at a rate of 350 per boatload every halfhour, visit the island and for a seven month period they encountered the first large-scale political use of Alcatraz since the Indian occupation from 1969 to 1971. Yet it is important to note that for the last 20 years or so there have been concerted efforts to promote and market Alcatraz around the notion of 'freedom' rather than 'confinement' (with tour guides emphasising the island's role as a nature reserve and seabird sanctuary, while also highlighting how it inspired the Red Power movement during the occupation). Of course, most of the tourist visitors to the island are drawn to it as Alcatraz remains a notorious icon of imprisonment, which the federal government carefully crafted in the 1930s and Hollywood blockbusters have perpetuated ever since (Loo and Strange, 2000).

A leading definition of contemporary art is that it makes you see the world differently and what distinguishes Weiwei from his contemporaries is he 'consistently diverts attention away from his work toward its ethical context' (Thornton, 2014:9). The juxtaposition of his extraordinary conceptual art installations in one of the major sites of prison tourism raises important questions on the relationships between art and activism in carceral space. His project clearly resonates with the National Park Service's longstanding drive to situate Alcatraz in a larger narrative of American liberty and freedom. These elaborate efforts to shift the public meaning of the site are undoubtedly a response to the rise of 'dark tourism' (Lennon and Foley, 2000), which has been condemned as an inappropriate and immoral way to commemorate human suffering and distressing events. Elsewhere I have argued that as criminologists have become increasingly concerned with the visual - as images of crime, harm and punishment across new and old media - there is a growing need for criminology to rethink its relations with the power of spectacle and appetite for the traumatic (Carrabine, 2011). Drawing on research recently conducted on tourism at Alcatraz the following conclusion was found:

More often, tourists became involved with the spectacle of the island and the commodification of the experience and not with the history of the island (which is a primary focus of most ranger-led tours) or the prison system in the context of its sociopolitical location in the US (which is depicted in multiple exhibits in the Exhibit Hall). Few tourists reported participating in the range-led tours and, often I found the Exhibit Hall empty, while the halls of the Main Cellblock were always full of plugged-in tourists taking photographs. The design of the Alcatraz experience permits visitors to participate in a form of forgetting that serves as an agent of reification.

(Gould, 2014:281)

Despite the best efforts of the 'memory managers' their educational endeavours to narrate a complex story are frequently undone by the commercial and entertainment values, which have long exploited the theme park marketing potential of 'the Rock' (Strange and Kempa, 2003).

It is in this context that Weiwei's installations can be situated, as an ambitious attempt to radically alter the meanings of incarceration at this historic site. Figure 2 is another striking example, here a giant paper dragon kite, with eyes incorporating the Twitter logo and a body carrying quotations from activists who have been imprisoned or exiled, is also tellingly confined in a building once used for prison labour. Meanwhile in the medical wing the toilets, sinks and bathtubs overflowed with porcelain white flowers (see Figure 3) quietly 
transforming the utilitarian fixtures into delicate bouquets and like the dragon kite they allude to traditional forms of Chinese art. But in this instance they also evoke Mao's "let a hundred flowers bloom" moment of tolerating free expression in the 1950s, before a brutal government crackdown. Some of the artworks were interactive, encouraging viewers to listen to voices of dissent singing or reciting poems inside small, isolated prison cells or even to get directly involved. In the dining hall visitors were offered the opportunity to correspond personally with individual prisoners by writing postcards addressed to some of the detainees represented in 'Trace'. The postcards were adorned with images of birds and plants from the countries where the prisoners are held, which also serves to reference the strange transformation of Alcatraz from federal penitentiary to nature reserve in the recent past.

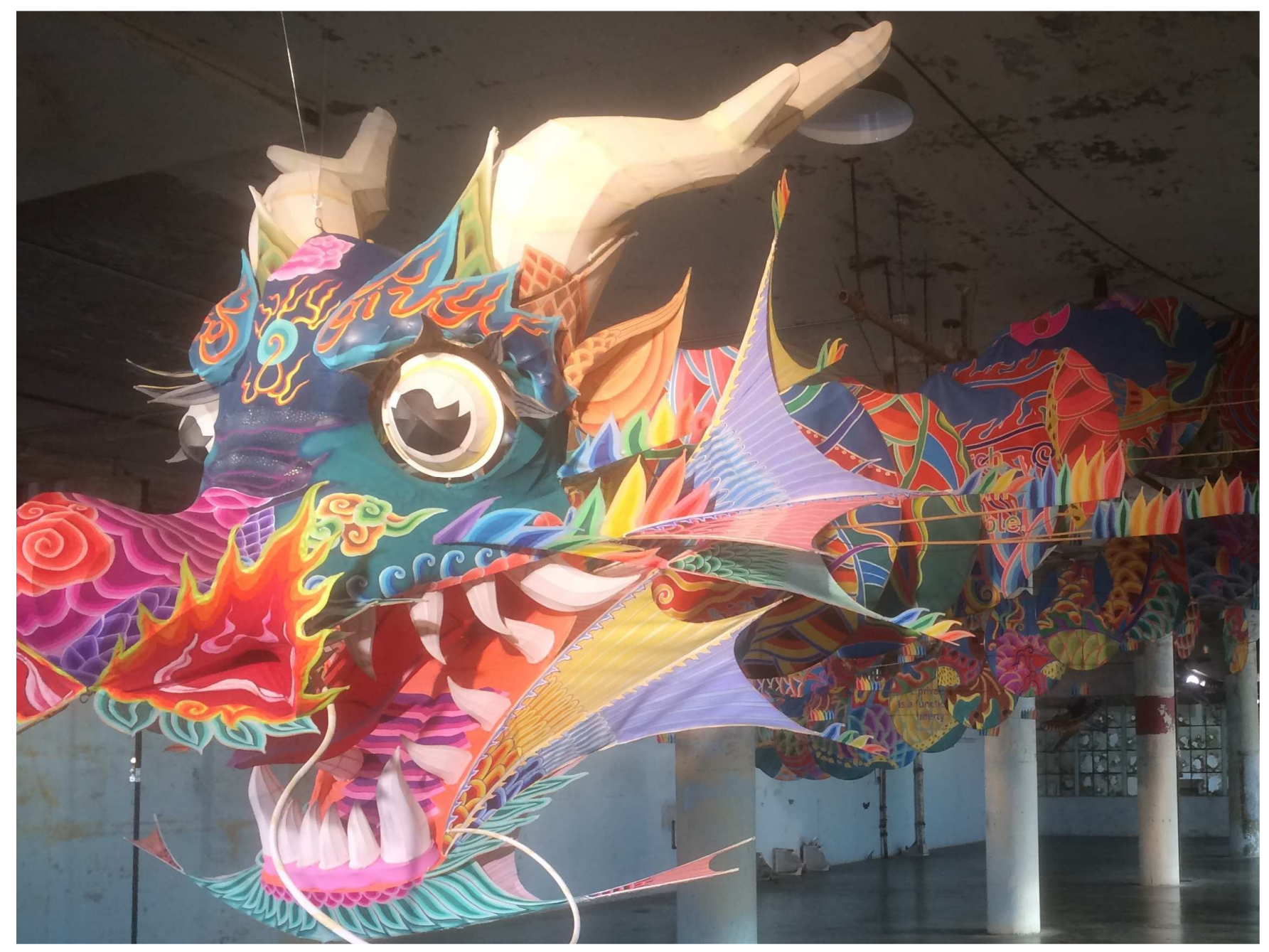

Figure 2: 'With Wind' from @Large: Ai Weiwei on Alcatraz. Photograph: Eamonn Carrabine, November 2014. 


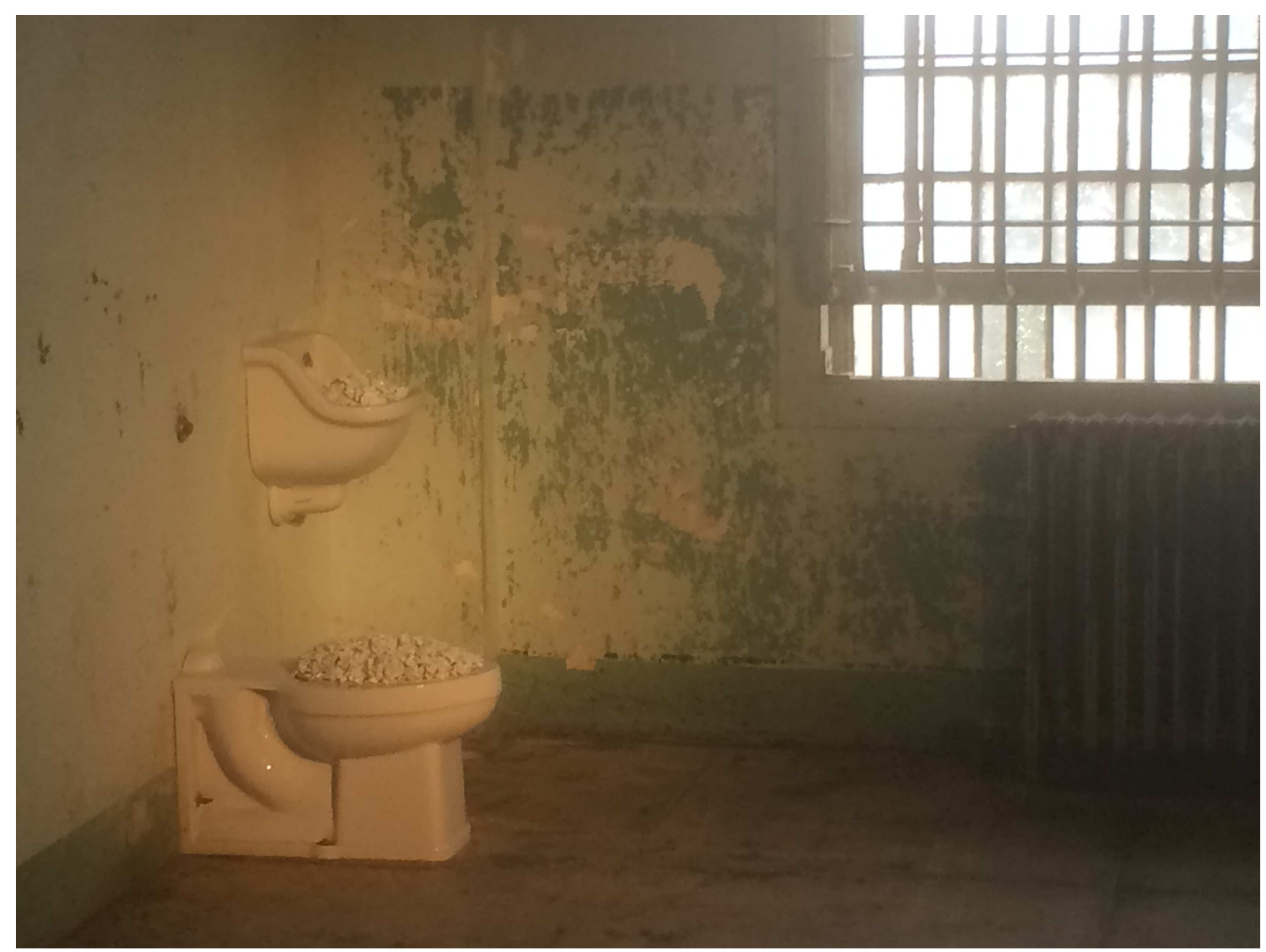

Figure 3: ‘Blossom' from @Large: Ai Weiwei on Alcatraz. Photograph: Eamonn Carrabine, November 2014.

An accusation often levelled against the tourist experience encountered at Alcatraz is that it offers up an 'apolitical space' (Gould, 2014:284) that trivialises the prison's dark past and precludes any real learning or remembering of the institution in US history. Although conceptual art can be, and has often been, criticised for its 'obscurity', 'pointlessness' and the 'inane effusions' that surround it (Hughes, 1991:384), there is no doubt that Weiwei's installations - ranging from the monumental to the intricate - are the manifestation of an idea. That they were displayed not in an art gallery or exhibition space, but at a major tourist attraction, to visitors who may or may not be well disposed to contemporary art, is all part of the movement's initial critique of the aesthetic principles of modernist art and the institutions that supported it. Central was the ambition to make art an intellectual encounter, so as to provoke an awareness of cultural and political contexts among viewers, and one strategy has been the use of 'artistic devices to confuse or alienate a sense of place' (Perry, 2012:266). Here the notion of site-specificity is closely tied to the idea of a technically accomplished, theatrical spectacle, where the audience participatory potential is emphasised and the meanings generated involve the artist 'working over' in some kind of distinct way 'the production, definition and performance of "place"" (Kaye, 2000:3, emphasis in original). Although we will never know the extent to which Weiwei's art shifted perceptions of Alcatraz it certainly offered up the possibility of disturbing them and posed critical questions 
on the nature of confinement by taking up activist concerns in ways that hammer away at the conceptual barriers between art and politics.

If the example of Alcatraz illustrates some of the dynamic ways in which "frames of remembrance" (Strange and Kempa, 2003:391) are constructed, so that visitors encounter traces of past trauma and suffering, then these issues are thrown into sharp relief by the transformation of genocidal sites of mass murder into memorial museums commemorating a violent past. The renowned French historian Marc Bloch (1967), who co-founded the Annales School of social history (and was later executed by a German firing squad in 1944), made an important distinction between two kinds of comparative history: one approach is to draw comparisons between societies fundamentally alike (such as medieval France and England), and the other makes comparisons between the fundamentally unalike (such as France and Japan). Each strategy is instructive, but in different ways. The particular details can open up an understanding of broader social processes, recurring patterns and the social organisations that produce them. The next empirical case study, on Cambodia's 'Killing Fields' and S-21 secret prison, offers an opportunity to analyse iconic power and the spectacle of suffering in a non-Western setting. The comparison returns us to the heart of the 'thanatopic tradition' (that is, the private contemplation of death in public places) so that dark tourism can be regarded as a 'contemporary mediating institution between the living and the dead' (Stone, 2013:1566).

\section{Ghosts of the Khmer Rouge}

The title of this part of the chapter is taken from Nick Heavican's (2011) photo essay on the memorials documenting the genocide perpetrated in Cambodia by the Khmer Rouge between 1975 and 1979, under the dictatorship of Pol Pot. The Khmer Rouge attained power after five years of civil war (1970-1975), which itself was a destructive 'sideshow' of the Vietnam War (Shawcross, 2002). Although it was largely an indigenous revolution the US economic and military destabilisation of Cambodia was a major factor shaping Pol Pot's rise and formation of a 'prison camp state' in the name of 'Democratic Kampuchea' (Kiernan, 1996:9). The regime hermetically sealed the country from the outside world and immediately embarked on a horrifying rule of terror that would cause the death of 2 million people, almost a third of the country's population (Chandler, 2008). The atrocities committed against civilians were carried out in a Maoist inspired 'total revolution', to forge an 'entirely new, productive communal society' (Tyner et al, 2012:858). Within hours of marching into Phnom Penh on 17 April 1975, which for the Khmer Rouge constituted the beginning of 'Year Zero', there began the forced removal of all inhabitants from the Cambodian capital city into agricultural collectives and labour camps. It was a brutal campaign of social and spatial cleansing that sought to rid the country of its urban, educated and professional classes so as to construct a pure, homogenous and self-sufficient peasant society.

Driven by an agrarian, anti-materialist ideology the new regime sought to completely dismantle everyday life and the many social institutions surrounding it. As David Chandler puts it:
Almost at once, and without explaining their rationale, the Khmer Rouge forcibly emptied Cambodia's towns and cities, abolished money, schools, private property, law courts, and markets, forbade religious practices, and set almost everybody to work in the countryside growing food. 
(Chandler, 2000:v)

By the time a Vietnamese invasion, on 7 January 1979, forced the Khmer Rouge from power (though remnants retreated into the jungle and waged a guerrilla war that lasted a further two decades) it gradually became clear that in such a brief period so many had perished from starvation, untreated disease, exhaustion as well as torture and execution in orchestrated, state administered violence. Most of the deaths, and all of the executions (estimated at nearly $1,000,000)$, resulted from a security apparatus dedicated to overseeing the rapid transformation of Cambodia's 'economic development' (Tyner and Devadoss, 2014:4). At the centre of the system was S-21, a former high school in Phnom Penh that had been converted into secret prison in October 1975, where 14,000 prisoners were killed (Chandler, 2000). Hundreds of thousands of victims were executed in the countryside, and the mass graves in which they were buried are the infamous 'killing fields' of Cambodia. The agricultural character of the regime 'saw many of these victims bludgeoned to death with crude instruments including axes, bamboo poles, and ox-cart axels' while others 'had their throats cut or were hacked to death with machetes' (Dalton, 2015:59).

No doubt it is because of the sheer scale of these atrocities that a complex politics of memory has arisen in post-Genocide Cambodia. The Tuol Sleng Museum of Genocidal Crimes in Phnom Penh opened in 1980, just months after the end of Khmer Rouge rule, at the S-21 interrogation and torture facility and continues to operate today. As do the killing fields of Choeung Ek, ten miles east of the capital, where prisoners from S-21 were taken to be murdered. When the site was discovered in the early 1980s the remains of 9000 bodies were found in mass graves, 'many were headless, naked, their hands tied; the separated heads were blindfolded' (Sion, 2014:104) and is but one of more than 500 sites of mass murder that have been unearthed (Williams, 2004:240). The Cambodian government and their Vietnamese advisors immediately set about defining the Khmer Rouge as 'genocidal' and 'fascist' to prompt comparisons with Hitler's Germany and downplay the regime's distorted socialist ideology (Chandler, 2008:360). To facilitate this tactic these two sites were quickly established as internationally visible places exposing the violent horrors perpetrated under Pol Pot to the wider world and to ensure the 'continued production of a coherent memory of the past' (Hughes, 2003:26). They have since become major tourist destinations, attracting thousands of visitors every year, and while there are other memorial sites these are mostly in the provinces, inaccessible and not easily identifiable to foreign visitors.

The reason why scholarship has largely focussed on Tuol Sleng and Choeung Ek lies in the political agenda surrounding these memorials and what it means to display the crimes of the Khmer Rouge in this way. For instance, it has been argued that 'these highly visible and officially commemorated sites serve to obfuscate other, more mundane sites (and practices) of violence' in everyday 'landscapes and legacies of violence that are "hidden in plain sight"" (Tyner et al, 2012:854). It is here that the question of iconic power is posed most acutely and can be seen in the controversies generated by atrocity photography. There are two predominant types: the action shot, depicting and preserving some moment of horror, and the identification picture, often in the form of a headshot and used to identify victims who were later killed or disappeared (Williams, 2007:56). As part of its permanent exhibition the Tuol Sleng museum displays thousands of photographic portraits of prisoners produced between 1975 and 1979, initially passport-sized prints, stapled to the detainees case files they deliberately employ Bertillon's famous mug-shot perspective (Dalton, 2015:79). The images were not incidental to S-21, rather the entire 'photographic documentation process was 
indicative of a larger bureaucratic effort to establish political legitimacy' (Tyner and Devadoss, 2014:366). The mug shots, selected and enlarged by East German photographers in 1981 have been posted on numerous boards ever since the museum opened (Chandler, 2000:27). Furthermore, it has been argued that the portraits 'have become "undisciplined envoys" of Cambodia's past, circulating on a global scale and through various media' (Hughes, 2002:24).

Crucial was the discovery in 1993 of some 6,000 photographic negatives in a rusting filing cabinet in the museum's archive by two North American photojournalists, Douglas Niven and Christoper Riley, who embarked on a project of cleaning, cataloguing and printing of the S-21 images. It is clear that their aims were not simply to recover and place the photographs in the Tuol Sleng museum setting, but 'to go global with exhibitions and a publication (which involved holding copyright on the photographs) - necessarily involved the photographs in the circulations of international news and visual arts media' (Hughes, 2003:30). There is no doubt that the global exposure of the photographs generated considerable interest in Cambodia, but important questions remain over the ongoing circulation of the images. Paul Williams addresses some of these issues in his discussion of one of the most reproduced headshot pictures, of a mother and child, in the following way:

The combination of the woman's youthful beauty, her resigned expression, and the infant in her arms is visually poignant and speaks eloquently of innocence. Beyond its callous overtones, the dilemma that arises from "preferring" some headshots over others is partly due to a modern paradigm that holds that the dual powers of photography - generating documentary records and creating works of art - should be kept separate. The conventional separation of headshots and portraiture in both style and intent is conventionally maintained due to their allied connotations of government identification versus artistic expression, or state subject versus creative personhood. While the technical conventions of the portrait and headshot are similar, they are assumed to show only either intimate character or bureaucratic supervision and reform.

(Williams, 2007:66-7, emphasis in original)

As he goes on to argue, it is when these categories become blurred that ethical questions come to the fore, as the controversies surrounding their display in a fine art context makes clear.

From May to September 1997 a selection of twenty-two prisoner portraits from Tuol Sleng went on public display at the Museum of Modern Art (MoMA) in New York in an exhibition titled Photographs from S-21: 1975-1979. Rachel Hughes (2003) has described the heated debates that ensued over their display, where Niven and Riley were criticised for selling artquality prints from the Tuol Sleng archive, and for holding copyright over the pictures, while the exhibition itself failed to acknowledge the connections between Cambodia's modern history and the United States. Others argued that through 'selecting those images that were most aesthetically satisfying and emotionally powerful, the curators performed their own kind of culling' and by radically divorcing them from 'the conditions of their creation, and by exhibiting only a digestible number, the images at MoMA were granted autonomy from the location and magnitude of what occurred' and consequently lose much of their 'evidential status' (Williams, 2007:67). By presenting them in such a museum context they become 'colonial spoils', 'exotic' displays that reinforce an 'enduring power imbalance within and 
against which the contact work of travel, exhibition and interpretation occurs' (Hughes, 2003:36). It is important to finish this discussion by recognising that for Cambodians memory and memorialization are not performed at either the main sites of Tuol Slong or Choeung Ek, or for that matter on official holidays, which serve other purposes and are directed to international tourists. Rather, as Brigitte Sion suggests:

remembrance of the genocide does take place, but quietly, traditionally and locally - in each village, in each stupa, next to the pagoda, on religious holidays. There, human dignity is respected, mourning rituals have meaning and the spirits of the murdered can eventually find rest.

(Sion, 2014:116)

\section{Conclusion}

By contrasting a contemporary art installation at Alcatraz with the display of genocidal evidence in an exhibitionary setting the intention has been to explore the contention that 'we can understand how we recapture the past only by understanding how it is preserved by our physical surroundings' (Halbwachs, 1925/1992:146). I want to conclude by further examining this proposition in the Cambodian context. Anyone who has visited Tuol Sleng and Choeung Ek will have been struck by just how unsettling and disturbing an experience it is, which is partly to do with their raw proximity to death and trauma. Their 'untouched appearance' has been described in the following way:

Tourists to other sites of genocide have become accustomed to artifacts and buildings presented "as is" that are, in fact, heavily mediated. Roped sections, glassed walls, guides and docents, restricted areas: all are parts of a typical, and passive, encounter with the "real thing." By contrast, at Tuol Sleng and Choeung Ek the general absence of guards or other visitors provides the opportunity to explore-to one's nervous limits. Inside the cells are wire torture beds to touch, hastily laid and bloodstained brick walls to lean against, and rusted ammunition boxes and barbed wire to handle. The unhindered intrusion produces a heightened sensitivity about how far to enter and how long to stay.

(Williams, 2004:242, emphasis in original)

As mentioned above, the museum acquires social authority by managing ways of seeing and here the shocking display of physical horrors was designed to achieve political goals from the outset, one which emphasised the Vietnamese liberation of the country from its murderous rulers. Today the sites operate as major tourist attractions that rely on the display of gruesome horrors to create considerable revenue. As the Lonely Planet guidebook advises, 'Tuol Sleng is not for the squeamish' (cited in Sion, 2014:101).

The risk is that the sites are experienced as 'theaters of gruelling historical spectacle' (Williams, 2004:243) and this is certainly the case with the enormous memorial stupa constructed in 1988 at Choeung Ek. Dominating the site the structure is stacked with more than 8,000 skulls and bones visible through glass windows on all sides. Although the design of the stupa 'is inspired by Khmer religious motifs, it is wholly antithetical to Khmer religious practice' (Tyner et al, 2012:860). According to Khmer Buddhist beliefs people who die suddenly should be buried or cremated on the site, as quickly as possible after death. Violent deaths are 'particularly inauspicious' and they necessitate immediate cremation to 
allow 'the spirit to move into the next karmic realm, instead of haunting the place of death forever' (Sion, 2014:109). Since traditional funerary rituals could not be performed this explains why some Cambodians find it 'a highly dangerous place and refuse to visit the memorial' (Hughes, 2004:276). For others the human remains have 'lost their spiritual value and elicit only mild interest from locals' (Sion, ibid).

Most tourists will be oblivious to the complexities of Cambodian funerary custom but will often walk on clothing and bones that stick out of the ground as they traipse over mass graves. The physical remains - from the neatly arrange skulls in the stupa to the bodies still interred at the site - have become 'commodities' and 'continue to represent the "historical erasure" of Cambodia's victims' (Tyner et al, 2012:861). It is hard not to disagree with Derek Dalton's (2015:69) impression that one is left "not so much with a wealth of knowledge of the "how" and "why" of genocide, but rather a repository of sensations, impressions and feelings about the horrors I had been given a vicarious insight into' from visits to both sites. These sites have become iconic, but they are far from unique in the genocide and their contribution to the political uses of memory mobilised by the government is significant. Not least since they divert attention away from the need for justice. Former Khmer Rouge officials who participated in or witnessed genocidal crimes are still active in government and still enjoy impunity (Sion, 2014:102) to the extent that an 'officially enforced amnesia' (Chandler, 2008:356) sits uncomfortably alongside ongoing efforts by activists and scholars to register the broader context of the genocide. The selective memorialization of the past is bound up with a lack of reconciliation that continues to haunt the country, such that in a 'context of unattained justice the memorials' will 'remain disconnected from any historical narrative' (Williams, 2004:235).

\section{References}

Alpers, S. (1991) 'The Museum as a Way of Seeing', in Karp, I. and S. Lavine (eds) Exhibiting Cultures: The Poetics and Politics of Museum Display, Washington, DC: Smithsonian Institution Press.pp. 25-32.

Barton, A. and A. Brown (2015) 'Show me the Prison: The Development of Prison Tourism in Britain', in Crime, Media, Culture 11(3):237-258.

Bloch, M. (1967) Land and Work in Medieval Europe, London:

Carrabine, E. (2011) 'The Iconography of Punishment: Execution Prints and the Death Penalty', in The Howard Journal of Criminal Justice, 50(5):452-464.

Carrabine, E. (2016) 'Picture This: Criminology, Image and Narrative', in Crime, Media, Culture, 12(2):tbc

Chandler, D. (2000) Voices from S-21: Terror and History in Pol Pot's Secret Prison, Chiang Mai, Thailand: Silkworm Books.

Chandler, D. (2008) 'Cambodia Deals with its Past: Collective Memory, Demonisation and Induced Amnesia', in Totalitarian Movements and Political Religions, 9(2-3):355-369.

Dalton, D. (2015) Dark Tourism and Crime, London: Routledge.

Gould, M. R. (2014) 'Return to Alcatraz: Dark Tourism and the Representation of Prison

History', in Sion, B. (ed.) Death Tourism: Disaster Sites as Recreational Landscape, London: Seagull, pp.267-288.

Halbwachs, M. (1925/1992) On Collective Memory, Chicago: University of Chicago Press. Hoskins, A. (2003) 'Signs of the Holocaust: Exhibiting Memory in a Mediated Age', in Media, Culture \& Society, 25(1):7-22. 
Heavican, N. (2011) 'Photo Essay: Ghosts of the Khmer Rouge', in Humanity: An International Journal of Human Rights, Humanitarianism and Development, 2(1):9-13. Holliday, R., (2000), 'We've been Framed: Visualising Methodology', Sociological Review, 48(4):503-521.

Hughes, R. (1991) The Shock of the New: Art and the Century of Change, London: Thames \& Hudson.

Hughes, R. (2003) 'The Abject Artefacts of Memory: Photographs from Cambodia's Genocide', in Media, Culture \& Society, 25(1):23-44.

Hughes, R. (2004) 'Memory and Sovereignty in Post-1979 Cambodia: Choeung Ek and Local Genocide Memorials', in Cook, S. (ed.) Genocide Studies Monograph Series, 1:269-92.

Huyssen, A. (1994) 'Monument and Memory in a Postmodern World', in Young, J.E. (ed.)

The Art of Memory: Holocaust Memorials in History, Munich: Prestel Verlag.

Huyssen, A. (1995) Twilight Memories: Marking Time in a Culture of Amnesia. London:

Routledge.

Keil, C. (2005) 'Sightseeing in the Mansions of the Dead', in Social \& Cultural Geography, 6(4):479-494.

Kiernan, B. (1996) The Pol Pot Regime: Race, Power, and Genocide in Cambodia under the Khmer Rouge, 1975-1979, New Haven, CT: Yale University Press.

Lennon, J. and M. Foley (eds) (2000) Dark Tourism: The Attraction of Death and Disaster, London: Continuum.

Loo, T. and C. Strange (2000) " "Rock Prison of Liberation": Alcatraz Island and the American Imagination', in Radical History Review, 78:27-56.

Malraux, A. (1967). Museum Without Walls. London: Secker \& Warburg.

Perry, G. (2012) 'Border Crossings: Installations, Locatiosn and Travelling Artists', in

Edwards, S. and P. Wood (eds.) Art \& Visual; Culture 1850-2010: Modernity to

Globalisation, London: Tate.pp.249-283.

Kaye, N. (2000) Site-Specific Art: Performance, Place and Documentation, London:

Routledge.

Olcese, C. and M. Savage (2015) 'Notes Towards a "Social Aesthetic": Guest Editors'

Introduction to the Special Section', in British Journal of Sociology, 66(4):720-737.

Rose, G. (2014) 'On the Relation between "Visual Research Methods" and Contemporary Visual Culture', in The Sociological Review, 62(1):24-46.

Seaton, A. (1996) 'Guided by the Dark: From Thanatopsis to Thanatourism', in International Journal of Heritage Studies, 2(4):234-44.

Seaton, A. (2009) 'Thanatourism and its Discontents: An Appraisal of a Decade's Work with Some Future Issues and Direction', in T. Jamal and M. Robinson (eds.) The SAGE Handbook of Tourism Studies, London: Sage, pp.521-542.

Shawcross,W. (2002) Sideshow: Kissinger, Nixon, and the Destruction of Cambodia, New York: Cooper Square Press.

Shulze, R. (2014) 'Resisting Holocaust Tourism: The New Gedenkstätte at Bergen-Belsen, Germany', in Sion, B. (ed.) Death Tourism: Disaster Sites as Recreational Landscape, London: Seagull, pp.121-138.

Sion, B. (2014) 'Conflicting Sites of Memory in Post-Genocide Camboduia', in Sion, B. (ed.) Death Tourism: Disaster Sites as Recreational Landscape, London: Seagull, pp.97-120. Stone, P. (2006) 'A Dark Tourism Spectrum: Towards a Typology of Death and Macabre Related Tourist Sites, Attractions and Exhibitions', in Tourism 54(22): 145-160.

Stone, P. (2013) 'Dark Tourism and Significant Other Death: Towards a Model of Mortality Mediation', in Annals of Tourism Research 39(3):1565-1587. 
Strange, C. and M. Kempa (2003) 'Shades of Dark Tourism: Alcatraz and Robben Island', in Annals of Tourism Research, 30(2):386-405.

Thornton, S. (2014) 33 Artists in 3 Acts, London: Granta.

Tyner, J. and C. Devadoss (2014) 'Administrative Violence, Prison Geographies and the Photographs of Tuol Sleng Security Center, Cambodia', in Area 46/4: 361-368

Urry, J. (1990) The Tourist Gaze, London: SAGE.

Welch, M. (2012) 'Penal tourism and the "Dream of Order': Exhibiting early Penology in Argentina and Australia', in Punishment \& Society, 14(5):584-615.

Welch, M. (2013) 'Penal Tourism and a Tale of Four Cities: Reflecting on the Museum Effect in London, Sydney, Melbourne, and Buenos Aires', in Criminology \& Criminal Justice, 13(5):479-505.

Welch, M. (2015) Escape to Prison: Penal Tourism and the Pull of Punishment, New York: New York University Press.

Welch, M. and M. Macuare (2011) 'Penal Tourism in Argentina: Bridging Foucauldian and Neo-Durkheimian Perspectives', in Theoretical Criminology, 15(4):401-425.

Williams, P. (2004) 'Witnessing Genocide: Vigilance and Remembrance at Tuol Sleng and Choeung Ek', in Holocaust and Genocide Studies, 18(2):234-254.

Williams, P. (2007) Memorial Museums: The Global Rush to Commemorate Atrocities, Oxford: Berg.

${ }^{1}$ This work was supported by a Leverhulme Trust Major Research Fellowship, MRF-2014052 . 